\title{
INSTITUTIONAL ANALYSIS OF INTERREGIONAL SOCIO-ECONOMIC CONVERGENCE IN THE CONTEXT OF EUROPEAN INTEGRATION: INTERDISCIPLINARY METHODOLOGICAL APPROACH DEVELOPMENT
}

\author{
Oleg Kuklin', Mykhailo Kryvoruchko²
}

\begin{abstract}
Relevance. The problem of interregional convergence within EU-countries has been of great interest among scholars. Such an interest is explained by the fact that joining the European Union may cause deepening interregional disparities among EU-members. As a result, there is a need to develop a model of interregional convergence in socio-economic development that would help countries to face the challenges of regional development during the process of European integration. The multidimensional nature of issues relating to interregional disparities implies the usage of an institutional approach that allows an analysis combining economic and non-economic factors. The purpose of this paper is to develop an interdisciplinary methodological approach to the analysis of interregional socio-economic convergence in the context of European integration from the institutional perspective. Methodological basis. Valuable and very interesting studies along this research line have been undertaken by a number of scholars who have used different methodological approaches that include neoclassical analysis, "core-periphery" theory, institutionalism, "resource abundance curse" phenomenon. The outcomes of their studies serve as a solid ground for in-depth research on interregional convergence that allows analysing this phenomenon from different perspectives. However, the issues regarding the regional dimension of institutional influence on the socio-economic development in the context of European integration have not been thoroughly covered in the economic studies. Results. Based on analysis of theoretical and empirical studies in the areas of interregional disparities and institutional economics, the interdisciplinary methodological approach has been developed, which implies reaching the following objectives: 1 ) to analyse interregional disparities in EU-members within the framework of neo-classical growth theory, 2) to examine regional dynamics using methodology of "core-periphery" theory ("New Economic Geography"); 3) to research the presence of "resource abundance curse" phenomenon in the regional development in the EU-countries; 4) to examine the institutional dimension of interregional disparities; 5) to analyse position papers on the EU Cohesion Policy implementation to outline the institutional challenges of the latter. Therefore, the research output allows developing an interdisciplinary approach to the analysis of the institutional aspect of socio-economic convergence that combines a quantitative (empirical) and qualitative analysis.
\end{abstract}

Key words: European integration, interregional socio-economic convergence, institutional dimension of interregional disparities, neo-classical convergence analysis, New Economic Geography, resource abundance curse, the EU Cohesion Policy.

JEL Classification: B50, R10

\section{Introduction}

The problem of interregional convergence among EU countries has been of a great interest, which is explained by the fact that European integration may accentuate the level of interregional differences in EU-members; this requires searching for an adequate mechanism to transit the integration process with fewer economic and social losses for territorial development. The multidimensional nature of interregional disparities implies an institutional approach to developing the

\footnotetext{
Corresponding author:

${ }^{1}$ Cherkasy State Business-College, Ukraine.

E-mail: kuklin oleg@ukr.net

ORCID: http://orcid.org/0000-0001-6904-3496

${ }^{2}$ Cherkasy State Business-College, Ukraine.

E-mail: m.y.kryvoruchko@gmail.com

ORCID: http://orcid.org/0000-0001-6150-864X
} 
model of interregional convergence in socio-economic development.

Valuable and very interesting studies along this research line have been undertaken by Anders, Barro, Bevan, Bode, Coase, Havrylyshyn, Krugman, Lane, North, Sala-i-Martin, Tiffin, and others. These scholars have used different methodological approaches that include neo-classical analysis, "core-periphery" theory, institutionalism, "resource abundance curse" phenomenon. The outcomes of their studies serve as a solid ground for in-depth research on interregional convergence, which allows analysing this phenomenon from different perspectives. However, the issues regarding the regional dimension of institutional influence on the socio-economic development in the context of European integration have not been thoroughly covered in the economic studies.

Research into the institutional influence on economic development holds one of the prominent places in modern economics. The seminal works of $\mathrm{R}$. Coase (1937) and D. North (1990) laid the groundwork for this line of research within the framework of new institutionalism. A cornerstone idea of the new institutional theory is an assumption that a market, unfriendly to political and legal environments, increases the cost of transactions for economic agents, which has a negative impact on business activity. As a result, poorly developed institutions foster the existence and development of a black economy, inefficient distribution of public resources, and grabber-oriented economic activity.

A number of empirical studies indicate the presence of a significant correlation between indicators of institutional and economic development (see Bevan, Estrin, and Meger, 2004; Knack and Keefer, 1995; Gwarthey, Holcombe, and Lawson, 2004; Havrylyshyn and van Rooden, 2000). In addition, this approach illustrates a basic tenet of the "resource curse" phenomenon - the situation where a resource-rich country experiences a recession due to the functioning of market-unfriendly institutions (see Lane and Tornell, 1998; Robinson, Torvik, and Verdier, 2006; Mehlum, Moene, and Torvik, 2006; Kolstad, 2007).

Wide usage of the new institutional approach demonstrates high theoretical and empirical value and importance in modern economic studies. This theoretical and methodological approach also formed the underlying basis applied to analyses of institutional change in the post-communist transition countries, including Ukraine (see Anders, 2001; Tiffin, 2006; Black and Tarassova, 2003).

\section{Research objectives and methodology}

The current paper aims at developing an interdisciplinary methodological approach to the analysis of interregional socio-economic convergence in the context of European integration from the institutional perspective. Particularly, the research focuses on the analysis of theoretical and empirical studies in the area of interregional convergence aiming at formulating research objectives to examine the institutional dimension of interregional convergence in the EU member-states.

The institutional nature of the examined issue and its complexity determine the research framework that targets answering the following research questions within the scope of this study:

1. What research approaches could be applied in order to examine the interregional convergence with regard to its interdisciplinary dimension?

2. Does the empirical evidence on analysis of interregional development in Ukraine indicate convergent or divergent tendencies?

3. What methodological approaches could be applied to the development of the research framework of the model of interregional convergence in Ukraine? How adequate and accurate would such model be?

4. Could the same interdisciplinary methodological approach be applied to the analysis of interregional convergence in the EU-members?

5. Taking into account that interregional convergence analysis is based on the empirical (quantitative) basis, what type of qualitative analysis could be used to enhance the interdisciplinary nature of the research framework?

Taking the above-mentioned research questions, the research methodology implies usage of theoretical and empirical evidence in the area of convergence as a methodological basis; whereas, the application of the method of analysis, systematization, and generalization would allow one to formulate the core of a methodological approach to analysis of interregional convergence in the context of European integration.

\section{Results and discussions}

A rigorous foundation for the reduction of interregional disparities as a research topic was laid in the 1950s: the pioneering studies were undertaken by R. Solow (1956) and T. Swan (1956) laid the groundwork for the neo-classical economic growth theory. Further development of the convergence model was connected with the seminal works done by R. Barro and X. Sala-i-Martin (1991, 1992). These scholars are considered the creators of a simple and straightforward approach to the analysis of the economic systems' convergence, which was based on the econometric testing of the assumptions of a negative correlation between the dynamics of the output (income) growth rate and its initial absolute value.

Nowadays the neo-classical approach has a wide application in studies on cross-country and interregional convergence and divergence, in different countries' 
unions and associations, particularly, in the European Union. This research venue is closely related to the studies, in which the interregional disparities (which are very high) in Ukraine are analysed in the context of European integration. The research findings indicate the presence of a strong divergence in the level of available (disposable) income - (see Kryvoruchko, 2015a); another important conclusion that has been derived from the empirical analysis is a strong dependence of regional development on abundant natural resources, i.e., the more a region extracts and exports mineral resources, the better is its economic performance (see Kryvoruchko, 2015b). Therefore, there has been created a situation where public policy in regional affairs was influenced by particular interest groups, which were competing for the access to the mineral deposits, while ignoring the crucial factors of socio-economic development, such as productivity, social justice, and welfare.

A separate study examines the institutional influence on the interregional disparities in socio-economic development in Ukraine (see Kryvoruchko, 2015c). The research methodology was based on the new institutional approach and application of regression analysis: three empirical models consisting of the coefficients of variation of gross regional product per capita, available income per capita, salary per employee in place of dependent variables, and institutional governance indicators in place of independent ones, were tested on a linear correlation. The empirical evidence indicated that the correlation between the variation of available income and institutional governance was insignificant, despite that there was a strong and significant correlation with gross regional product and salary. The preliminary assumption on the negative sign of regression parameters did not come true; therefore, the research conclusion stated that the positive nature of institutional influence on the interregional disparities in Ukraine could be explained by the resource-oriented structure of Ukrainian economy: overall economic growth leads to speeding-up of economic development of the leading regions, which in turn, causes deepening interregional disparities.

Following the "core-periphery" theoretical and methodological framework (see Krugman, 1991; Bode and Mutl, 2010; Bosker, Brakman, Garretsen, and Schramm, 2010; Brakman, Garretsen, and Schramm, 2006), research has been undertaken in order to estimate the presence of either interregional convergence or divergence in Ukraine. The empirical evidence indicated a positive correlation between industrial market size and the level of available income per capita leading to the conclusion concerning the presence of interregional divergence in Ukraine (see Kryvoruchko, 2015d).

Understanding that the major issues in the regional development in Ukraine are institutional in nature, there hasbeendevelopedaninstitutionalmodelofinterregional convergence in socio-economic development.
Its methodological framework (see Kryvoruchko, 2016a) implies examining how the industrial and resource orientation of regional economy influences the institutional factor of regional development. The choice of variables indicating such a factor has been made in order to research two dimensions of institutional environment changes, namely, social and structural ones; crime rate and innovation market size has been chosen respectively as indicators to evaluate the two dimensions mentioned above. The institutional model of interregional convergence also implies examining the influence of social and structural factors of regional development on the socio-economic development on the regional level, the level of interregional disparities, and the institutional environment on the national level.

Empirical testing of correlations within the institutional-social convergence model indicates surprisingly positive correlations between industrial and resource orientation of a regional economy and the crime rate; crime rate as a determinant factor fosters socio-economic development on the regional level, reduces interregional disparities in wage level, and reflects the public's negative perception of government accountability in Ukraine. The controversial nature of such factors as the crime rate's impact on the convergence model leads to a reconsideration of the role of the crime rate; this indicator could be used in place of the institutional indicator on the national level along with other institutional indicators within the structural framework of the version of the institutional model.

Empirical correlation testing within the institutionalstructural convergence model indicates a positive influence of the industrial (but not the resource) orientation of a regional economy on the innovation market size; the innovation market size as a determinant factor has a positive impact on socio-economic development on the regional level; in addition, the innovation market size reduces interregional disparities in the level of disposable income per capita, and reflects a positive public perception of the control of corruption and government effectiveness, as well as reducing the crime rate on the national level.

Empirical evidence leads to the conclusion that the developed convergence model is adequate and accurate. The research outcome indicates the importance of structural reforms rather than social changes in order to reduce interregional disparities in Ukraine, to foster socio-economic development on the regional level, and to improve the overall institutional environment in Ukraine. This conclusion complies with the evidence that an innovation-driven economy is more favourable for interregional convergence than the resourceoriented one (see Kryvoruchko, 2016b).

Generalization of the analysed studies allows one to use their methodologies in order to examine the institutional mechanism of interregional convergence among EU countries. The EU-members differ by the 
structure of their national economies and the level of interregional disparities, which is the focus of the research to be undertaken.

The following research objectives would be achieved in order to examine the interregional disparities in socioeconomic development with respect to the complexity of this issue:

1. To analyse interregional disparities in EU-members within the framework of neo-classical growth theory, i.e. using $\beta$ - and $\sigma$-analysis.

2. To examine regional dynamics using the methodology of "core-periphery" theory ("New Economic Geography"), which is based on researching the correlation between wage/income level, interregional migration, and industrial market size.

3. To research the presence of the "resource abundance curse" phenomenon in the regional development in the EU-countries by analysing the correlation between regional growth rate and the share of mineral resources in the regional export/import.

4. To examine the institutional dimension of interregional disparities by analysing the influences of institutional governance and doing business indicators on the coefficient of variation of socio-economic development indicators.

Reaching the above-mentioned objectives would allow one to make a well-grounded conclusion from different perspectives on the presence of divergent or convergent tendencies in regional development. Understanding the different dimensions of regional dynamics will provide solid groundwork for formulating a methodology for the interregional convergence model, which purpose is to examine the institutional mechanism of the interregional convergence in socio-economic development in the context of European integration. The methodology implies an analysis of the correlation between institutional factors (which indicate social/ structural changes in the regional development) and interregional variation in socio-economic development, as well as regional socio-economic development indicators. Such an approach would allow evaluating the influence of the institutional factor both on regional development and on interregional disparities.

The proposed methodology could be applied to all EU-members or the groups of EU-countries with similar socio-economic characteristics, though there remains some flexibility. Cross-country and crossregional correlation analysis would be used as the research method along with single/multiple time series regression analysis.

An important component of an institutional approach to interregional divergence in the context of European integration is the analysis of the EU Cohesion Policy. The European Commission is implementing the Cohesion Policy aimed at reducing disparities within EU member-states and their regions. The EU Cohesion Policy has been of great interest to the scholars researching interregional cohesion in the context of European integration (see Bachtler, Mendez, and Wishlade, 2016; Dudek, 2014; Mendez and Bachtler, 2015).

Regardless of the progress in socio-economic convergence, good institutional governance remains an important challenge for the EU Cohesion Policy implementation effectiveness (see European Commission, 2017). In order to widen the scope of the empirical research on institutional governance's influence on interregional cohesion in the context of European integration, one should analyse political positions (position papers) on the Cohesion Policy implementation to bring a qualitative component into the research. Position papers are the documents published by the EU member states' national governments and research institutions as a response to the European Commission's call for consultations regarding different issues. The methodological basis for the analysis of position papers implies a research background in political agenda of European Union from the perspective of institutional development and decision-making (see Kreppel, 2002; Madeliene, Kreppel, Plechanova, and Verdun, 2015).

\section{Conclusions}

The research outcome indicates that within the scope of this paper, there has been developed an interdisciplinary methodological approach to the analysis of interregional socio-economic convergence in the context of European integration. Having answered the research questions, one has come to the following conclusions:

1. There are different research approaches that could be applied to the analysis of the interregional convergence with regard to its interdisciplinary dimension. Particularly, the neo-classical, coreperiphery, resource abundance and institutional governance methodological approaches allow outlining different aspects of interregional convergence.

2. Overall, the empirical evidence on analysis of interregional development in Ukraine indicates divergent tendencies. Another important conclusion is a strong dependence of regional development on abundant natural resources.

3. Neo-classical, core-periphery, resource abundance and institutional governance methodological approaches could be applied to the development of the research framework of the institutional model of interregional convergence in Ukraine. Empirical evidence indicates that the developed model is adequate and accurate.

4. The same interdisciplinary methodological approach could be applied to the analysis of interregional convergence in the EU-members. The EUmembers differ by the level of economic development and interregional cohesion; therefore, one would 
expect different empirical output within the proposed framework of analysis.

5. In order to enhance the interdisciplinary nature of the research framework, in addition to empirical (quantitative) analysis, the analysis of position papers on the EU Cohesion Policy could be added to the research framework as its qualitative component. Position papers are the officially published documents that express a view (position) on the EU Cohesion Policy implementation challenges and perspectives.

Therefore, the combination of classical and nonclassical methodological approaches to the interregional analysis provides the multidimensional foundation for examining potential challenges of European integration to the regional development. The proposed methodological approach implies the following two research lines. The first one is related to the institutional framework that is to be applied to the analysis of institutional governance and interregional convergence within the EU countries. The second one is related to studying political positions on institutional aspects of the EU Cohesion Policy implementation. Following these two research lines allows combining quantitative and qualitative methods, as well as enhancing the interdisciplinary nature of the developed research methodology.
The undertaken research on the methodological approach to the institutional analysis of interregional socio-economic convergence in the context of European integration lays down the foundation for quantitative and qualitative research. The further development of this research line depends on the research output of the conducted analysis. Particularly, one could consider grouping the EU countries based on common convergent/divergent tendencies, institutional governance issues, core-periphery relations, and resource/innovation-driven type of the economy. Another important area of further research on interregional convergence could relate to an analysis of the institutional strengths/weaknesses of the EU Cohesion Policy implementation, and their impact on the institutional environment in the EU countries. Such research could point out either the EU Cohesion Policy implementation fosters cross-country and interregional institutional cohesion within the European Union.

The outlined research perspectives require a significant volume of scholarly work, both quantitative and qualitative. Its scope goes beyond a journal article; therefore, a number of research papers or a monography would have an appropriative scope of the proposed research lines as a further development of the examined issue within the current paper.

\section{References:}

Anders, A. (2001). Building Capitalism: Lessons of the Postcommunist Experience - Washington, DC, Policy Brief, Carnegie Endowment for International Peace.

Bachtler, J., Mendez, C., Wishlade, F. (2016). Evolution or Revolution? Exploring New Ideas for Cohesion Policy 2020+. Glasgow, University of Strathclyde, European Policies Research Center, EoRPA Paper 16/4.

Barro, R., Sala-i-Martin, X. (1991). Convergence across States and Regions. Brookings Papers on Economic Activity, $1,107-182$.

Barro, R., Sala-i-Martin, X. (1992). Convergence. Journal of Political Economy, 100(2), 223-251.

Bevan, A., Estrin, S., Meger, K. (2004). Foreign Investment Location and Institutional Development in Transition Economies. International Business Review, 13(1), 43-64.

Bode, E., Mutl, J. (2010). Testing Nonlinear New Economic Geography Models. Institute for Advanced Studies, Economics Series 253.

Bosker, M., Brakman, S., Garretsen, H., Schramm, M. (2010). Adding Geography to the New Economic Geography: Bridging the Gap Between Theory and Empirics. Journal of Economic Geography, 61, 793-823.

Black, B., Tarassova, A. (2003). Institutional Reforms in Transition: a Case Study of Russia. Supreme Court Economic Review, vol. 10, The Rule of Law, Freedom, and Prosperity, 211-278.

Brakman, S., Garretsen, H., Schramm, M. (2006). Putting New Economic Geography to the Test: Free-Ness of Trade and Agglomeration in the EU Regions. Regional Science and Urban Economics, 36, 613-635.

Coase, R. (1937). The Nature of the Firm. Economica, 4(16), 386-405.

Coase, R. (1937). The Problem of Social Cost. Journal of Law and Economics, 3, 1-44.

Dudek, C. M. (2014). The History and Challenges of Cohesion Policies. Jean Monnet/Robert Schuman Paper Series, 14(2) [Working Paper].

European Commission (2017). Improving Institutions - Luxemburg, Publications of the European Union, Seventh Report on Economic, Social and Territorial Cohesion.

Gwarthey, J., Holcombe, R., Lawson, R. (2004). Economic Freedom, Institutional Quality, and Cross-Country Differences in Income and Growth. Cato Journal, 24, 205-233.

Havrylyshyn, O., van Rooden, R. (2000). Institutions Matter in Transition, but So Do Policies. IMF Working Paper № 0070 .

Knack, S., Keefer, P. (1995). Institutions and Economic Performance: Cross-Country Tests Using Alternative Institutional Measures. Economics and Politics, 7(3), 207-227. 
Kolstad, I. (2007). The Resource Curse: Which Institutions Matter? Chr. Michelson Institute Working Paper WR2007:2.

Kreppel, A. (2002). The European Parliament and the Supranational Party System: A Study of Institutional Development - Cambridge University Press (Studies in Comparative Politics).

Krugman, P. (1991). Increasing Returns and Economic Geography. Journal of Political Economy, 99(3), $483-499$.

Kryvoruchko, M. Yu. (2016a). Teoretyko-metodologhichni zasady instytucionaljnoji modeli mizhreghionaljnoji konverghenciji socialjno-ekonomichnogho rozvytku v umovakh jevrointeghraciji [Theoretical and Methodological Foundations of the Institutional Model of Interregional Convergence in Socio-Economic Development in the Context of European Integration]. Molodyj vchenyj, 1(28), 84-87. (in Ukrainian)

Kryvoruchko, M. (2016b). Interregional Convergence and Divergence in the Resource-Oriented and InnovationDriven Economies: Evidence from Ukraine and South Korea. International Journal of Economics and Society, 2(5), 53-60.

Kryvoruchko, M. (2015a). Doslidzhennja mizhreghionaljnoji konverghenciji v rivni zhyttja naselennja Ukrajiny [A Study on the Interregional Convergence in the Living Standards of the Population of Ukraine]. Aktualjni problemy ekonomiky, 8(170), 302-307. (in Ukrainian)

Kryvoruchko, M. Yu. (2015b). Resursna orijentovanistj eksportu ta importu jak faktor socialjno-ekonomichnogho rozvytku reghioniv Ukrajiny [Resource-Oriented Exports and Imports as a Factor of the Socio-Economic Development of the Regions of Ukraine]. Biznes Inform, 9, 112-122. (in Ukrainian)

Kryvoruchko, M. (2015c). Institutional Influence on the Interregional Disparities in the Socio-Economic Development in Ukraine. International Journal of Economics and Society, 1(1), 10-13.

Kryvoruchko, M. Yu. (2015d). Analiz mizhreghionaljnoji dyferenciaciji socialjno-ekonomichnogho rozvytku v Ukrajini v ramkakh «Novoji ekonomichnoji gheoghrafiji» [Analysis of the Interregional Disparities of the SocioEconomic Development in Ukraine within Framework of the «New Economic Geography»]. Biznes Inform, 3, 50-55. (in Ukrainian)

Lane, P., Tornell, A. (1998). Voracity and Growth - Harvard Institute for International Development, Development Discussion Paper № 654 .

Madeline, H., Kreppel, A., Plechanova, B., Verdun, A. (eds.) (2015). Decision Making in the EU before and after the Lisbon Treaty - London and New York, Routledge Press.

Mehlum, H., Moene, K., Torvik, R. (2006). Institutions and the Resource Curse. The Economic Journal, 116, 1-20. Mendez, C., Bachtler, J. (2015). Permanent Revolution in Cohesion Policy: Restarting the Reform Debat. EoRPA Paper 15/4, paper prepared for the $36^{\text {th }}$ meeting of the EoRPA Regional Policies Research Consortium at Ross Priory, Loch Lomonside, 4-6 October 2015.

North, D. (1990). Institutions, Institutional Change and Economic Performance - Cambridge, Cambridge University Press.

Robinson, J., Torvik, R., Verdier, T. (2006). Political Foundations of the Resource Curse. Journal of Development Economics, 79, 447-468.

Solow, R. (1956). A Contribution to the Theory of Economic Growth. The Quarterly Journal of Economics, 70(1), 65-94.

Swan, T. (1956). Economic Growth and Capital Accumulation. Economic Record, 32, 334-361.

Tiffin, A. (2006). Ukraine: The Cost of Weak Institutions. IMF Working Paper № 06/167. 